The Geneva Papers on Risk and Insurance, 17 (No. 63, April 1992), 257-266

\title{
MIGA : Long Term Political Risk Insurance for Investments in Developing Countries
}

\author{
by Leigh P. Hollywood*
}

\section{Introduction}

In 1988, the Multilateral Investment Guarantee Agency (MIGA) was established as a new member of the World Bank Group. MIGA's purpose is to encourage foreign investments in developing countries by providing: (a) long term political risk insurance to private investors, and (b) advisory services to governments in developing countries to assist them in creating a responsive and attractive investment climate. The focus of this article is on investment insurance which is provided through the Agency's guarantee program.

The full history of MIGA's creation is treated in a number of articles and publications, the most notable of which is Mr. Ibrahim Shihata's book MIGA and Foreign Investment ${ }^{\text {. }}$ This article will provide a short review of the impetus behind MIGA's creation, followed by a description of MIGA's political risk guarantee program, a discussion of MIGA guarantee activities since its founding, the procedural aspects of obtaining MIGA political risk insurance coverage, and the outlook for the future. A brief overview of the events which precipitated the creation of MIGA provides an appropriate starting point.

\section{The need for private investment in developing countries}

As a result of various factors, but especially the international debt crisis, private capital flows into many developing countries in the early 1980 s were reduced to a trickle. Between 1979 and 1984 direct investment flows to these countries declined by an average annual rate of $7 \%$. International banks scaled back or terminated their lending programs; there was a $13 \%$ average annual decline in total bank lending to developing countries during the 19791984 period. Foreign investors grew cautious about making new investments in developing countries, particularly as prospects for remitting profits dimmed.

Assistance from multilateral and bilateral organizations to developing countries were less affected in this period, but were clearly inadequate to meet the capital needs of these countries and to compensate for the loss of private capital inflows. As a consequence, many developing countries in the 1980s found themselves in the position of being net exporters of capital, and many have had to renegotiate their debt obligations. Overall, lack of

\footnotetext{
* Vice President, Guarantees, The Multilateral Investment Guarantee Agency.

' Ibrahim F. I. Shihata, MIGA and Foreign Investment (Boston: Martinus Nijhoff Publishers, I988).
} 
foreign and domestic capital, and the need to use export earnings to repay foreign debt, combined to limit investment in developing countries, which in turn resulted in lower economic growth and attendant political and social difficulties.

Although it is widely acknowledged that developing countries need to increase their economic activity through increased investment, limited domestic capital is available and foreign private investment capital is scarce. Foreign investors, while acknowledging the potential for high returns on many projects, are often unwilling to incur the added "noncommercial", or political, risks associated with investments in developing countries.

Both developed and developing countries have long recognized the value of trying to modify private investors' views of the prospective risks and returns associated with potential investments. Many developing countries have created investment incentive programs and sought to simplify their investment regulations and tax codes so as to make themselves more attractive to investors. ${ }^{2}$ Developed countries have created programs to selectively promote investment flows to developing countries; they recognize that private capital flows can complement their bilateral and multilateral developmental assistance efforts. ${ }^{3}$

More than twenty countries, including all the larger OECD countries, have created specific political risk insurance programs (sometimes referred to as investment guaranty programs) to help their national investors overcome concerns about political risks. These national programs include, among others, the Overseas Private Investment Corporation (OPIC) in the United States, the Export Credits Guarantee Department (ECGD) of the United Kingdom, the Export Insurance Division of the Ministry of International Trade and Industry (EID/MITI) in Japan, the Export Development Corporation (EDC) of Canada, and Treuarbeit of Germany.

These programs, while superficially similar, have some important asymmetries in both the coverages offered and their availability to investors. While generally quite successful in overcoming investors' fears and trepidations about political risk, investment insurance is not widely utilized. This is due not so much to a lack of demand as to the limits of these national programs. Varying eligibility criteria related to the differing national mandates of these programs have often led to restrictive underwriting practices. In some instances, the limited financial resources of each agency also served to reduce the availability of investment insurance.

By the early 1980s, the critical need of the developing world for more capital, coupled with the acknowledged cost-effective role that investment insurance entities were already playing, created an environment where the formation of a multilateral investment insurance agency was both possible and desirable. The advantages of such an entity were clear. By "aggregating" investment insurance from many countries, offering uniform protection regardless of the nationality of the investor and providing cover to multinationally financed investments, a multilateral agency could provide investment protection which complements

2 See, for example, the excellent study by Louis T. Wells, Jr. and Alvin G. Wint, "Marketing a Country: Promotion as a Tool for Attracting Foreign Investment" (Occasional Paper, Foreign Investment Advisory Service: 1, April, 1990).

3 See "Survey of Official Programs to Promote Foreign Direct Investment in Developing countries". A report by the Forcign Investment Advisory Service. 1991. This pioneering report reviews the bilateral programs of the 14 OECD countries and several multinational institutions. 
the efforts of the various national agencies. Such an entity would be far less politicized than national agencies in its decisions to issue coverage. In addition, a multilateral insurance agency could, through reinsurance of and coinsurance with existing national agencies, contribute to a broader, more effective range of coverages for investors venturing into the developing world.

From the perspective of most developing countries, the alleviation of investors' concerns about political risks through a multilateral insurance organization seemed to be of particular benefit. If the insurer was affiliated with an international development institution, then the issuance of investment insurance could not only facilitate investments that may not have otherwise been made, but could help ensure that the investments would be mutually beneficial to both the investor and the host country.

Due to a confluence of these and many other factors, the Multilateral Investment Guarantee Agency (MIGA) came into being in the summer of 1988 .

\section{The Multilateral Investment Guarantee Agency}

In this section, the broad outline of MIGA's investment insurance program will be described.

\section{a) Membership}

Membership in MIGA is open to all countries that belong to the World Bank, but to become a MIGA member, each country has to ratify MIGA's Convention, subscribe to a predetermined amount of capital, and contribute a portion of the capital. As of December 3, 1991, there were 111 countries signatory to the MIGA Convention, of which 85 have ratified and 74 have fully completed the requirements for membership (including payment of the cash portion of the capital subscription). MIGA has an authorized capital of US\$ 1,080 million, of which the 85 ratified countries have subscribed to an amount of capital totalling approximately US $\$ 840$ million. Table 1 indicates the membership of MIGA as of December 3, 1991.

It is important to note that there is a distinction in the membership, reflected in the Table, between so-called Part I member developed countries (primarily OECD countries) and the Part II member developing countries. For insurance purposes, investments deriving from individuals or companies domiciled in any member country are eligible, but only if the destination of the investment is a project located in a Part II, developing country.

b) Investment insurance coverage

Through MIGA's Guarantee program, an investor contemplating investing in a MIGA member developing country can obtain long term insurance coverage against specified political risks for which may arise in connection with the investments. The types of insurance coverage can be obtained are:

(1) Currency inconvertibility

Protects an investor against the inability to convert dividends, profits, or proceeds from the disposal of the insured investment from local currency into a specified freely convertible currency. The coverage also protects against government actions which prevent the transfer of the proceeds out of thc host country. 
Table 1:

Membership of MIGA as of December 3, 1991

$\begin{array}{ll}\text { Albania } & \text { Ghana } \\ \text { Angola } & \text { Grenada } \\ \text { Bahrain } & \text { Guyana } \\ \text { Bangladesh } & \text { Hungary } \\ \text { Barbados } & \text { Indonesia } \\ \text { Bolivia } & \text { Ireland } \\ \text { Botswana } & \text { Italy } \\ \text { Burkina Faso } & \text { Jamaica } \\ \text { Cameroon } & \text { Japan } \\ \text { Canada } & \text { Jordan } \\ \text { Chile } & \text { Kenya } \\ \text { China } & \text { Korea, Republic of } \\ \text { Congo } & \text { Kuwait } \\ \text { Cote d'Ivoire } & \text { Lesotho } \\ \text { Cyprus } & \text { Luxembourg } \\ \text { Czechoslovakia } & \text { Madagascar } \\ \text { Denmark } & \text { Malawi } \\ \text { Dominica } & \text { Malaysia } \\ \text { Ecuador } & \text { Malta } \\ \text { Egypt, Arab Republic of } & \text { Mauritius } \\ \text { Ethiopia } & \text { Namibia } \\ \text { Fiji } & \text { Netherlands } \\ \text { Finland } & \text { Nigeria } \\ \text { France } & \text { Norway } \\ \text { Germany } & \text { Oman } \\ \text { (2) Expropriation } & \end{array}$

Pakistan

Papua New Guinea

Poland

Portugal

St. Lucia

St. Vincent and the Grenadines

Saudi Arabia

Senegal

Spain

Sri Lanka

Sudan

Swaziland

Sweden

Switzerland

Togo

Tunisia

Turkey

United Kingdom

United States

Vanuatu

Western Samoa

Zaire

Zambia

\section{(2) Expropriation}

Protects an investor against losses attributable to measures taken by the host government which have the effect of depriving the investor of its ownership of, control over, or rights to its investment. Both direct and indirect ("creeping") expropriation are covered.

\section{(3) War and civil disturbance}

Protects an investor against losses arising from any military action or politically motivated violence in the territory of the host country which destroys or damages tangible assets of the project enterprise, or which interferes with its operations (business interruption coverage). War and Civil Disturbance is further defined to embrace events of War, Revolution, Insurrection and Civil Strife, including Terrorism and Sabotage, so long as there is a political objective.

\section{(4) Breach of contract}

Protects an investor against losses arising from a repudiation or breach by the host government of a contract with the investor, in situations where the investor is denied justice. Insurance would typically cover an agreement fundamental to the operation and success of a project, such as a concession agreement, contract of work, production sharing arrangement, etc. The agreement would be expected to have a disputes resolution mechanism built into it, calling for third country arbitration of any disputes. A failure of the arbitral mechanism, primarily non-payment of an award by the government to the insured, is the political risk covered under breach of contract, not the breach itself. 


\section{c) Eligibility criteria}

MIGA insurance is available to investors considering, but not yet irrevocably committed to making, a new investment in a developing country. Both the investor's home country (country of incorporation or the country where the majority of its sharcholders arc located) and the country in which the investment is made must be members of MIGA.

Types of contribution that can bc covered by MIGA include equity, shareholder loans and shareholder guaranties of loans. In ccrtain circumstances MIGA can, after approval of its Board, insure loans to a project enterprise by a party which is not an equity holder, such as a commercial bank - provided that MIGA also insures one of the shareholders in the project enterprise. In addition, MIGA can insure "indircct equity-type investments", (e.g. technology transfer, licensing and franchising contracts) provided that the terms of these contracts are more than three years, and that the return on the investment is tied to some positive measure of the performance of the project enterprise.

\section{d) Terms of coverage}

Coverage is typically available for a period of 15 years, but can be as short as three years and as long as 20 years. MIGA commits itself for the full term of the insurance contract on a non-cancellable basis regardless of events in the host country, whereas the investor has the right to reduce individual coverages, or terminate the contract any time after the third anniversary. The insurance can cover up to $90 \%$ of the investment amount at risk; additional coverage is available for future earnings attributable to the insured investment. The maximum amount of guarantee for any one project is currently limited to US\$ 50 million.

Premium is decided on a case by case basis after review of the project for which insurance is required. To assist an investor contemplating political risk investment insurance for an investment, MIGA has published an "Investment Guarantee Guide" in which premium "base rates" are listed. This permits calculation of an approximation of what the investor's premium is likely to be. The actual premium will vary around these base rates, and will be influenced by the specific risks associated with the project.

This approach to setting a premium rate is based on MIGA's belief that the risk of each project is somewhat unique. This can result in considerable differences between the rates charged for different projects in the same country, as well as the possibility that one coverage ratc may be offered at a discount to its base rate while another may be at a premium - cven for the samc project. The cxpectation is that over MIGA's whole portfolio, the rates charged will tend to approximate the base rate. Investors have accepted this system since it is bascd on the principle of being equitable among insureds. It is clearly supcrior to a simple, flat rate scheme for all projects in all countries or to a country rating approach which is used by many export credit agencies. The latter system, in particular, covcrs up real diffcrences in risk between different projects within the same country.

MIGA provides both a "current" and a "standby" coverage (the latter at a substantially lower premium rate) for the purpose of reducing the overall level of premium commensurate with the amount of investment currently at risk. This provides the investor with the opportunity to annually adjust its current insurance coverage and, through the standby mechanism, to reserve capacity for coverage of future increases in the net book value of the investment. 


\section{e) Types of projects}

MIGA's insurance program is open for all types of investments, except military projects. MIGA has received applications for mining, manufacturing, and agriculture projects, and for investments in the financial services and transportation sectors. In addition, preliminary applications have been filed for "Build-Own-Transfer" (BOT) type projects involving power generation and other infrastructural activities.

Although MIGA can only insure new investments, it is not limited to new projects. The Agency also considers applications for coverage of new investments applied to the expansion of existing enterprises, the acquisition and modernization of existing companies, and for privatizations, as long as the investor files its application before actually making, or committing to make, the investment. Some of the first investments insured by MIGA illustrate the wide variety of projects and types of contributions which can be covered.

\section{f) Examples of recent projects insured by $M I G A$}

Expansion of a copper mine in Indonesia. MIGA was asked to insure the investor's equity contribution for an expansion aimed at doubling the capacity of an existing project. Although the total equity contribution far exceeded MIGA's current project limit, MIGA's US $\$ 50$ million insurance policy against the risks of Breach of Contract and War nevertheless facilitated the expansion of the project.

Acquisition of a manufacturing company in Hungary. The project, which is a joint venture between a Hungarian bank and the investor, involves the acquisition of an existing manufacturing company, which will be restructured, modernized and expanded. MIGA reinsured OPIC, the official US agency for investment insurance, for US $\$ 30$ million of the total insurance amount sought by the investor of US $\$ 130$ million. Coverage is provided against Currency Transfer and Expropriation risks.

New gold and silver mine in Chile. In this transaction, MIGA also worked with the investor's national insurance agency - in this case, the Export Development Corporation of Canada - in providing coverage for a shareholder loan guaranty. MIGA is reinsuring US $\$$ 50 million of the total coverage amount of US\$158 million against the risks of Currency Transfer, Expropriation and War and Civil Disturbance.

New Aquaculture company in Chile. MIGA insured a small investor which, in joint venture with a local partner, is establishing an aquaculture facility. MIGA is providing equity and standby coverage for an amount of approximately US $\$ 2$ million against the risks of Currency Transfer, Expropriation and War and Civil Disturbance.

Fertilizer manufacturing in Bangladesh. Two Japanese equity investors are insured by MIGA for loan guaranties they have put up as part of the financing package. MIGA is covering some US $\$ 20$ million against the risks of expropriation and war and civil disturbance. Other insurers in the project include the national investment insurers from Denmark, Japan, the United Kingdom and the United States.

Restaurant operations in Chile. A US restaurant company opening a series of joint ventures in Chile was insured by MIGA against the risks of currency transfer and war and civil disturbance. The amount of coverage was US $\$ 5$ million. 
Cellular telephone networks in Chile. Two separate companies setting up independent cellular communications services in Chile were insured by MIGA against the risks of currency transfer, expropriation, and war and civil disturbance. Approximately US $\$ 10$ million of coverage was provided to the two companies.

\section{g) Application procedures}

Since MIGA can cover only new investments, an investor who is interested in obtaining MIGA coverage must, before committing to invest, register the project with MIGA by filling a Preliminary Application. The registration is free of charge and does not commit either the investor or MIGA to proceed with the application. Once the investor has more information about the project and has decided that insurance coverage is desired, a Definitive Application should be filed. This application, including supporting project documentation, (e.g. a feasibility study), will form the basis for MIGA's underwriting decision.

MIGA's analysis of the project will center on political risk issues, but the Agency will also, based on the documentation provided by the investor, assure itself that the project is financially and technically sound and that it does not have a harmful impact on the environment. MIGA ean normally offer insurance cover within four months from the date of receipt of a complete Definitive Application. The investor, of course, is under no obligation to accept the offer.

\section{h) Application to date}

A brief review of the application record of MIGA indicates that MIGA's founders were correct in assessing the unmet demand for investment insurance across a wide spectrum of industries and countries. From the inception of MIGA, some 500 applications for coverage have been received. Of these, 440 were accepted for registration; approximately twothirds of the remainder were for investments in countries not yet signatories to the MIGA Convention, and about one-third were rejected because the projects themselves were not eligible for coverage.

Since preliminary applications represent only potential investment plans of a wide variety of investors, MIGA anticipates that the majority will not be implemented in the near future. For those that eventually do go forward, the decision-making process typically takes two to three years, with more complex projects and projects in more difficult country environments often taking five years or more. As of December, 1991, about 50 registered projects have proceeded to the point where the investors are reasonably certain that the project will go forward and that they wish to complete their applications for insurance coverage.

MlGA has completed its underwriting review for more than half of the projects and made offers of coverage to the investors.

At this offering point, neither MlGA nor the investor is committed to the offering or acceptance of coverage. Once offered, the investor has a limited amount of time to decide whether the coverage is desired. If so, the contract is signed and the premium is paid for the first year; MIGA then countersigns. As of the date of signature by MIGA, MIGA is committed to the contract on a non-cancellable basis for the term of the contract, typically 15 years, regardless of what may occur in the host country, including a drying up of foreign exchange reserves, an illegal succession of government or an outbreak of war. This long term commitment on MlGA's part is highly valued. The insured, on the other hand, may 
reduce its coverage at any time or may cancel the entire contract at any anniversary date after the third year. In addition, should the insured sell its interest to another MIGA-eligible buyer, the insurance contract can be assigned to the new buyer.

Tables 2 and 3 illustrate the diversity of projects which have been brought to MIGA, the countries of the investors, and the host countrics of the contemplated investments.

Table 2:

Total applications by industry as of June 30, 1991

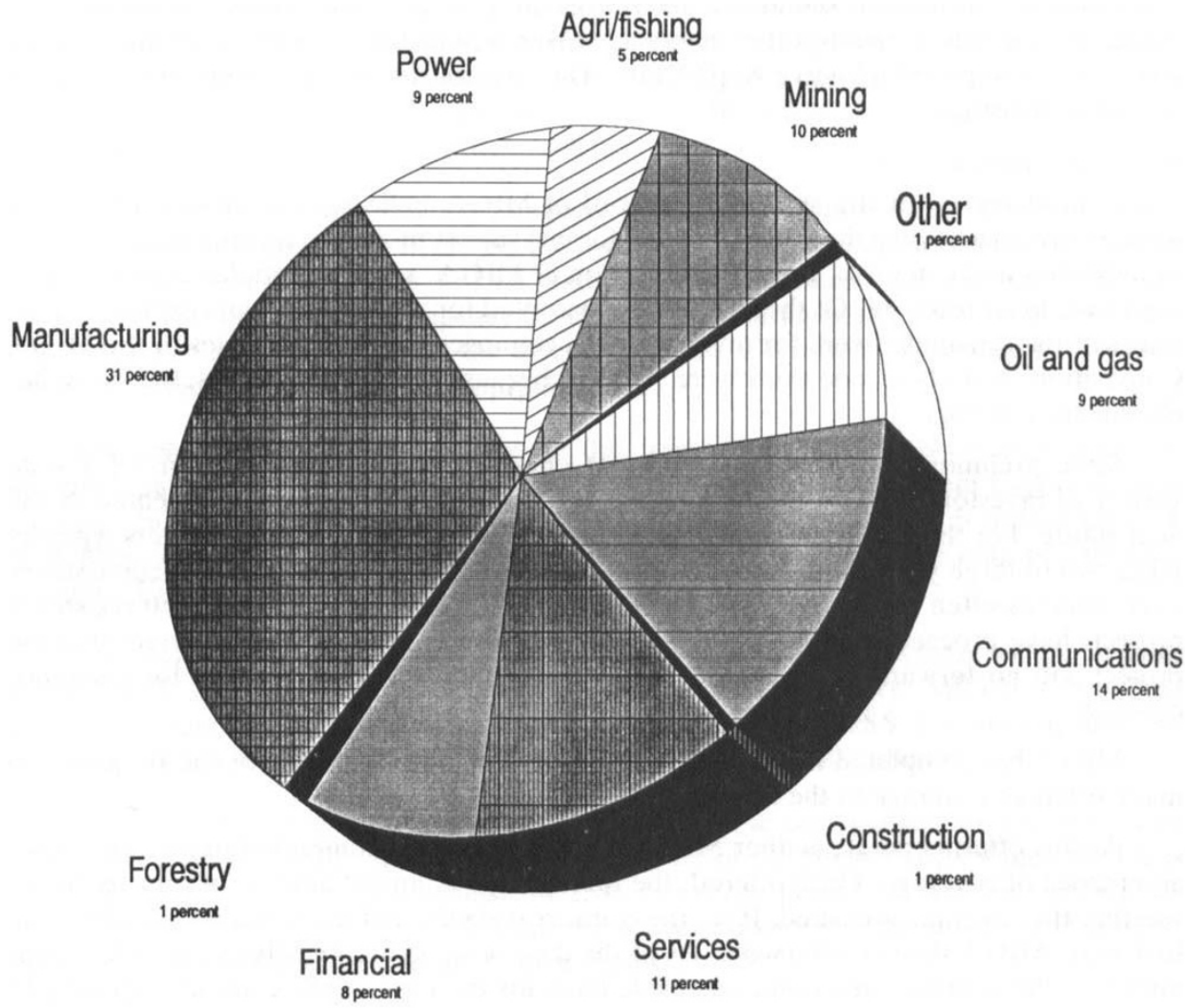


Table 3:

Country location of potential projects and country of origin as of December 30, 1991

Host Countries of projects for which

Preliminary Applications for Guarantee

have been registered

\begin{tabular}{l} 
Albania \\
Angola \\
Argentina \\
Bangladesh \\
Benin \\
Bolivia \\
Botswana \\
Brazil \\
Bulgaria \\
Burkina Faso \\
Cameroon \\
Chile \\
China \\
Colombia \\
Congo \\
Costa Rica \\
Cote d'Ivoire \\
Czechoslovakia \\
Ecuador \\
Egypt \\
El Salvador \\
Equatorial Guinea \\
Ethiopia \\
Ghana \\
Greece \\
Grenada \\
Guinea \\
Guyana \\
Haiti \\
Honduras \\
Hungary \\
Indonesia \\
Jamaica \\
Jordan \\
\\
\hline
\end{tabular}

Kenya
Korea, Republic of
Lesotho
Madagascar
Mali
Morocco
Namibia
Netherlands Antilles
Nicaragua
Nigeria
Oman
Pakistan
Papua New Guinea
Paraguay
Peru
Philippines
Poland
Romania
Senegal
St. Kitts and Nevis
Sierra Leone
Sri Lanka
Sudan
Swaziland
Tanzania
Togo
Trinidad and Tobago
Turkey
Uganda
Uruguay
Yemen, Republic of
Yugoslavia
Zaire
Zambia
Zimbabwe

Origin of companies registered Preliminary

Applications for Guarantee :

Belgium
Canada
China
Denmark
Finland
France
Germany
Italy
Jamaica
Japan
Luxembourg
Mauritius
Netherlands
Nigeria
Norway
Philippines
Saudi Arabia
Spain
Sweden
Switzerland
Tunisia
United Kingdom
United States

Belgium

Finland

France

Germany

Jamaica

Japan

Mauritius

Netherlands

Nigeria

Philippines

Saudi Arabia

Sweden

Switzerland

United States 


\section{i) Existing portfolio}

MIGA has issued sixteen contracts of guarantee as of Dcember 3, 1991. The spread of risk across countries (Chile, Poland, Turkey, Madagascar, Bangladesh, Hungary and Indonesia) is remarkably good for a start-up situation. The source countries for these investments are likewise broad (Canada, Luxembourg, Japan, France, the Netherlands, Denmark and the United States). MIGA's maximum contingent liability under guarantees issued and outstanding as of June 30, 1991 totaled US \$191 million. ${ }^{4}$

\section{Conclusion and outlook for the future}

The volume of applications that MIGA has received in the last two years is one indicator of the existence of a strong demand for investment insurance which MIGA's prescient founders had correctly identified in the early 1980s. There clearly are many potential investors who are in some way inhibited by political risk considerations and who are either ineligible for investment insurance coverage from existing sources, or unable to obtain adequate coverage from customary sources. This effectively means that there are numerous market "niches" which MIGA can potentially scrve. Two of these niches arc worthy of particular note.

The potential for MIGA reinsurance of, or coinsurance with, national insurers is of particular significance. This facet of MIGA's business should steadily grow in the $1990 \mathrm{~s}$; for risk management reasons, it is a particularly attractive option for the smaller OECD national programs. (In addition to two existing reinsurance arrangements, MIGA should sign several more next year.)

Another major niche, largely unserved by anyone - including MIGA - is composed of developing country investors who are potentially interested in projects in other developing countries. These prospective investors are rarely even aware that political risk investment insurance exists, but most would not have access to any long-term program other then MIGA. Obviously, MIGA faces a tremendous challenge in finding and serving these potential investors in the 1990s.

A great deal of effort in MIGA's initial two years of operation has been devoted to staff recruitment, setting up organizational systems, preparing basic informational brochures and disseminating this information on a preliminary basis. In the future more resources and greater effort will be devoted to the actual business of reaching potential investors, processing applications, writing guarantees and facilitating investment to devcloping countries.

The same considerations that motivated member countries of the World Bank to create MIGA in the 1980s are not only still relevant for the 1990s but have become more critical. Private investment flows to the developing world are still insufficient to meet the economic needs of the developing countries and political risk considerations remain a significant inhibiting factor in corporate decision-making about investments in those countries. Hence, it was foresightful for World Bank member countries to create the Multilateral Investment Guarantee Agency to help address these concerns and to design it in a fashion which complements existing national insurance schemes.

\footnotetext{
${ }^{4}$ See MIGA's 1991 Annual Report, for complete financial statements.
} 